\title{
Ex ante life cycle assessment of GaAs/Si nanowire-based tandem solar cells: a benchmark for industrialization
}

\author{
Georgios Pallas $^{1}$ (D) $\cdot$ Martina G. Vijver ${ }^{1} \cdot$ Willie J. G. M. Peijnenburg ${ }^{1,2} \cdot$ Jeroen Guinée ${ }^{1}$
}

Received: 17 July 2019 / Accepted: 7 July 2020 / Published online: 19 July 2020

(C) The Author(s) 2020

\begin{abstract}
Purpose The goal of this study is to perform an ex-ante life cycle assessment (LCA) of the emerging gallium-arsenide nanowire tandem solar cells on silicon $(\mathrm{GaAs} / \mathrm{Si})$ and to provide a benchmark for the commercialization of the technology. The environmental impacts and energy payback time (EPBT) of the GaAs/Si modules are compared with those of the incumbent single-Si modules. Parameters and efficiencies most relevant to be optimized in order to commercialize the technology are identified and discussed. Methods Two production routes for GaAs/Si solar cells are being up-scaled: the growth of GaAs nanowires on a native substrate, peel-off, and transfer to a silicon substrate (transfer route) and the direct growth of GaAs nanowires on a silicon substrate with assistance of a silicon-dioxide $\left(\mathrm{SiO}_{2}\right)$ nanotube template (direct growth route). Two ex-ante LCAs for the different manufacturing routes and an LCA for the incumbent single-Si technology were conducted. Environmental impacts of the GaAs/Si technology were assessed and compared with the incumbent. Various scenarios regarding sensitive parameters and processes were modeled - such as modeling several industrial scale tools, the energy consumption of sensitive processes, the number of substrate reuses, the frequency of re-polishing the wafer, and benchmarking the scale of improvement of major impact drivers.

Results and discussion The analysis showed that, if expected process efficiencies are achieved, a $28 \%$ efficient GaAs/Si module performs 5 to $20 \%$ better (transfer route) and 20 to $30 \%$ better (direct growth route, except the ozone depletion impact) compared with an 18\% efficient single-Si module, for all impact categories assessed - climate change, land use, acidification, ozone depletion, freshwater, marine, terrestrial ecotoxicity, eutrophication, human toxicity, and photochemical oxidation. Critical hotspots identified include the use of gold, trifluoromethane $\left(\mathrm{CHF}_{3}\right)$, and a GaAs wafer. The EPBT of the GaAs/Si nanowire tandem module is in between 1.37 (expected process efficiencies achieved) and 1.9 years (worst case scenario), while the EPBT of the single-Si module is 1.84 years. Results can be considered as a benchmark for the successful commercialization of the technology.

Conclusions If $28 \%$ efficient $\mathrm{GaAs} / \mathrm{Si}$ nanowire tandem modules are developed, expected process efficiencies are achieved, and at least 100 reuses of the GaAs substrate (transfer route) are realized; then, the GaAs/Si modules perform better compared with an $18 \%$ efficient single-Si module for most impact categories assessed. Conclusions from the ex-ante LCA are conditional (if-then) and can be used as a benchmark, allowing to quantify the efficiencies that need to be achieved to commercialize the technology.
\end{abstract}

Keywords Ex-ante $\cdot$ Prospective $\cdot$ Life cycle assessment $\cdot$ Emerging technologies $\cdot$ Benchmark $\cdot$ Photovoltaics $\cdot$ Nanomaterials . Solar cells

Responsible Editor: Chris Yuan

Electronic supplementary material The online version of this article (https://doi.org/10.1007/s11367-020-01791-z) contains supplementary material, which is available to authorized users.

Georgios Pallas

g.pallas@cml.leidenuniv.nl

1 Institute of Environmental Sciences (CML), Leiden University, PO Box 9518, Leiden 2300 RA, The Netherlands

2 National Institute of Public Health and the Environment, Center for the Safety of Substances and Products, P. O. Box 1, Bilthoven 3720 BA, The Netherlands

\section{Introduction}

Solar energy is expected to play a significant role in climate change mitigation (Rogelj et al. 2018). Photovoltaic (PV) installation has grown from $13.4 \mathrm{GW}$ of cumulative installed PV capacity in 2008 to more than $400 \mathrm{GW}$ at the end of 2017, and is expected to grow beyond 3000 GW by 2040 (IEA - PVPS 2009, 2017; ITRPV 2018; IEA - World Energy Outlook 2019). The current dominant PV technologies, with more than $90 \%$ of the global installed PV capacity (IEA 2017), are the crystalline-silicon ( $\mathrm{Si}$ ) technologies. These crystalline-Si PVs 
are, however, bounded to a theoretical conversion efficiency limit of 29.4\% (Richter et al. 2013).

In order to overcome the efficiency limitation of current commercial photovoltaics, novel solar technologies are required. One example of such an innovation is the use of nanomaterials, for instance nanowires (NWs), in solar PVs (Otnes and Borgström 2017; Borgström et al. 2018). A combination of commercial crystalline-Si solar cells and III-V materials - materials with good semiconductor propertiescan result in solar cells with higher conversion efficiency. The higher efficiency is achieved by combining different materials that can convert different parts of the light spectrum into electricity, resulting in a more efficient solar cell (Wallentin et al. 2013). In this study, we consider a galliumarsenide (GaAs) nanowire solar cell on top of a crystalline silicon substrate. This is a two-junction solar cell (so-called tandem cell), in which the bottom junction consists of a singleSi solar cell and the top junction consists of a layer of nanowires. The current world highest efficiency of a III-V tandem solar cell on Si is $32.8 \%$ (Green et al. 2018) with the potential to reach efficiencies beyond 40\% (Almansouri et al. 2015; Essig et al. 2017).

One main disadvantage of the III-V multijunction solar cells is the high production cost (Essig et al. 2017) which until now has limited the use of such solar technologies in area-restricted and critical applications like space technologies (Chiu et al. 2014). Another concern is that, although the use of nanomaterials in solar cells has the potential to produce photovoltaic technologies with higher efficiencies, it may likely come with environmental trade-offs over the life cycle of these nano-based technologies (Klöpffer et al. 2007; Franklin 2015; Guineé et al. 2017). Previous life cycle assessment (LCA) studies have assessed the impact of the use of nanomaterials in different solar technologies. Amorphous silicon (Kim and Fthenakis 2011; van der Meulen and Alsema 2011; Mohr et al. 2013), organic (Tsang et al. 2016), polymer (Roes et al. 2009), quantum dot (Şengül and Theis 2011), perovskite (Zhang et al. 2015), and single-walled carbon nanotube (Celik et al. 2017) photovoltaics are among the technologies assessed so far. In many of those studies, the solar technologies in which nanomaterials were embedded showed increased carbon emissions compared with those PV cells without nano-embedded technologies, mostly due to energy intensive processes for the production of nanomaterials - see meta-analysis (Pallas et al. 2018). Furthermore, two studies have assessed the environmental performance of gallium-indium-phosphide/multi-crystalline silicon (Meijer et al. 2003) and gallium-indium-phosphide/gallium-arsenide (Mohr et al. 2007) tandem modules. These are studies that use more than 10 to 15 -yearold data for aggregated manufacturing processes for planar (not nanowires) III-V solar modules. In this study, we assess the environmental performance of novel early-stage of development manufacturing routes of GaAs nanowirebased solar modules.

To evaluate the environmental performance of emerging technologies at an early stage of development, ex-ante (or prospective or anticipatory) LCA can be used (Roes and Patel 2011; Walser et al. 2011; Arvidsson et al. 2014; Wender et al. 2014; Villares et al. 2016, 2017). An LCA is ex-ante when a technology studied exists at an early stage of research and development (R\&D) -i.e., at a lab or pilot scale-but is modeled for a projected future industrial/ commercial-scale production (Arvidsson et al. 2017; Guinée et al. 2018). Thus, by applying ex-ante LCA at a new technology under development, unintentional future environmental impacts of this technology can be identified, and prevention actions can be developed (Cucurachi et al. 2018).

The objective of our study is to benchmark the commercialization of the GaAs/Si nanowire tandem solar cells against existing technologies. This is done by identifying the efficiencies and technical characteristics that need to be achieved in order for the technology to be successful. To that end, an exante LCA was performed of up-scaled product systems for GaAs NW tandem solar cells on silicon $(\mathrm{GaAs} / \mathrm{Si})$ production, for two different manufacturing routes. Hotspots were identified in addition. As a starting point, lab-scale data of the different manufacturing routes have been used (Pallas et al. 2019).

Here, we first scale-up the lab-scale product systems for the two manufacturing routes and we perform an ex-ante LCA, including an impact assessment for a broad range of impact categories. Secondly, we compare the environmental performance of the two different manufacturing routes of the upscaled GaAs/Si NW technologies to the existing commercial single-Si technology. Finally, we optimize the product systems, and we identify all the hotspots of concern and the conditions under which the new technology outperforms the incumbent technology. Ultimately, a benchmark for the successful commercialization of the new technology with minimum impact on the environment is presented. The results of our analysis can lead technology experts to further improve the technology towards industrialization.

\section{Methodology}

\subsection{System description}

The GaAs/Si solar cell consists of two sub-cells: the single-Si bottom cell and the GaAs nanowire top cell. The GaAs (III-V materials) nanowires are grown ${ }^{1}$ in a process called epitaxy: either by a metal organic vapor phase epitaxy (MOVPE) or by

\footnotetext{
${ }^{1}$ Nanowire growth means the formation of the nanowire structure.
} 
a metal organic chemical vapor deposition (MOCVD) process. These two processes are essentially the same process ${ }^{2}$ (AZO Materials 2014). The GaAs NWs have a height of $1.5 \mu \mathrm{m}$, a diameter of $180 \mathrm{~nm}$ and grow in a temperature of about $650{ }^{\circ} \mathrm{C}$ (personal communication-IBM Research and Lund University).

For the production of the NW top cell, we model two different manufacturing routes which have been described in detail (Pallas et al. 2019). The first manufacturing route is the transfer route, in which the GaAs NWs grow on a GaAs (native) substrate by MOVPE, and then, they are peeled off and transferred to a silicon substrate (Wallentin et al. 2013; Anttu et al. 2014; Borgström et al. 2018). The second manufacturing route is the direct growth route, in which NWs grow directly on a silicon substrate by MOCVD, with the assistance of silicon dioxide $\left(\mathrm{SiO}_{2}\right)$ nanotubes that are developed on top of the silicon substrate (Borg et al. 2014; Schmid et al. 2015). Detailed information of the nanowire growth product systems is provided in the Supplementary material S1 and S2.

After NWs have grown and been placed on the single-Si wafer, the cell and module manufacturing processes follow. For the single-Si cell production, the module manufacturing, and the balance of system components required for the operation of the solar modules, well-established data exist in the literature (Jungbluth et al. 2012; Frischknecht et al. 2015). The product systems are shown in Fig. 1.

\subsection{Scaled-up system description}

Most processes in the product systems analyzed already exist at an industrial scale in the solar or the electronics industry. To up-scale the GaAs/Si nanowire tandem solar cells, we combine data from the lab measurements with data from industrial-scale processes found in the literature, data from the technology developers within the project, as well as their expert opinions with regard to up-scaling the lab processes and their related energy and material requirements.

Regarding the energy consumption of the system processes, values of already existing equivalent industrial processes have been used. In two cases, the energy consumption of proxy industrial processes from the silicon solar cell industry has been used in our baseline scenario. The two cases are the epitaxial process (MOVPE or MOCVD) for the growth of NWs (both routes) and the plasma-based dry etching processes (direct growth route). For the former, a large chemical vapor deposition (CVD) tool for silicon has been used as a proxy for up-scaling. For the latter, a dry etching tool for silicon has been used. These are based on discussions with the

\footnotetext{
${ }^{2}$ MOVPE and MOCVD are interchangeable in literature. The name MOVPE describes more specifically the underlying process.
}

technology experts within the NanoTandem consortium (EU H2020 - NanoTandem 2015).

Regarding the material consumption of the processes, combined data sources have been used. For those processes that already exist in an industrial setting, their specific material efficiencies have been used. For the wet etching and cleaning process steps, the material quantities required at the lab scale have been scaled proportionally to the average magnitude of wet etching and cleaning material requirements of the commercial wet etching processes in the silicon solar cell industry. For the dry etching processes in the direct growth route, the material quantities are not expected to differ compared with dry etching lab process values, and thus, the lab scale material quantities have been used (personal communication-IBM Research). Finally, the III-V material requirements of the epitaxial process, i.e., gallium and arsenic, have been calculated based on the expected up-scaled efficiency of the group III and group V metals (personal communication-Fraunhofer ISE). In particular, a backcasting approach has been used. The nanowire length (layer thickness), the dimensions, the III-V material composition, and the number of nanowires per wafer are known. The aimed output of the process is then combined with the expected efficiencies of the III-V materials (provided from the experts), and consequently, the input of III-V materials in the epitaxial process has been calculated. The remaining materials in the epitaxial processes have been up-scaled based on the best available technologies from several sources.

A detailed discussion regarding the up-scaling assumptions of each process is provided in the Supplementary material S3. An overview of the up-scaling of the two manufacturing routes is provided in the following sub-sections.

\subsubsection{Transfer route up-scaling}

In this route, there is a requirement of a native substrate for the growth of the III-V nanowires. The production of high pure III-V wafers is a complicated process, which requires significant amounts of materials and energy. In our analysis, we use a very detailed process inventory for the production of $625-\mu \mathrm{m}$-thick GaAs wafers from Smith (2018), including the production of polycrystalline GaAs boule, single-crystal GaAs boule, GaAs ingots, sawing the wafer with a diamond saw, pre-polishing and chemical mechanical polishing (CMP) of the wafer and cleaning, and finally quality control and packaging of the wafer. The aforementioned wafer thickness is essential in order to handle material losses during each CMP step and to achieve many substrate reuses (Woodhouse and Goodrich 2014). The inventory also includes the production of high purity gallium and arsenic, the synthetic diamond, the sawing slurry, and the CMP slurry. The detailed process data that have been collected are provided in the Supplementary material S6. An overview of the processes of the transfer route-specific processes for patterning the GaAs, the NW 


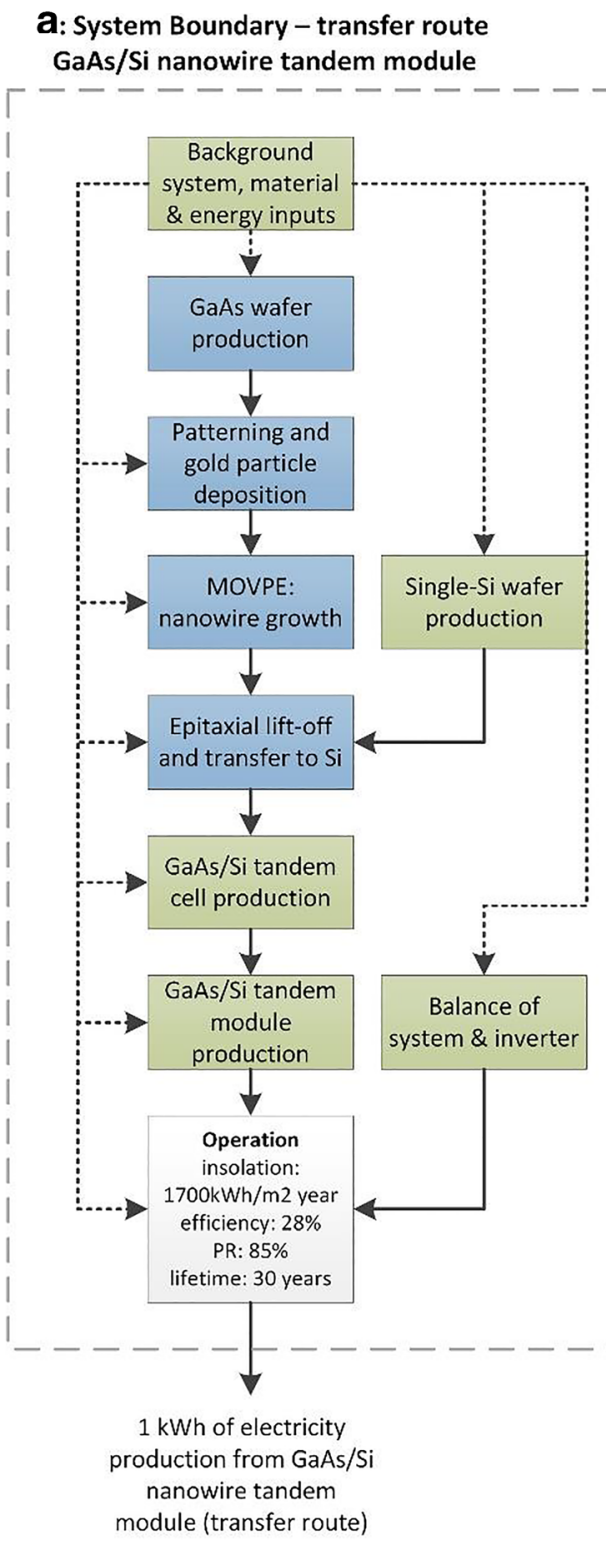

b: System Boundary - direct growth route GaAs/Si nanowire tandem module

C: System Boundary - incumbent Single-Si module

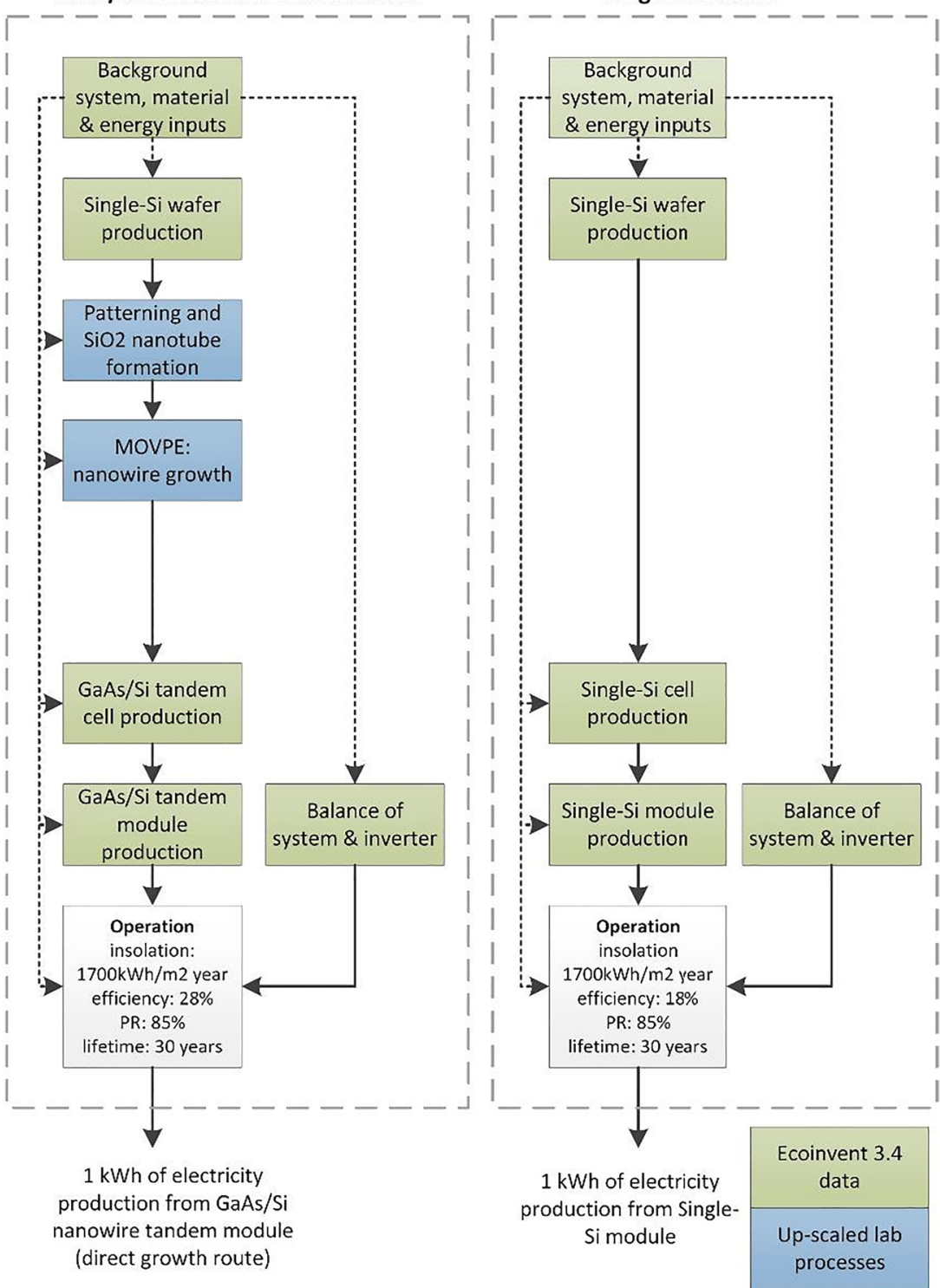

Fig. 1 Production systems of a GaAs/Si NW tandem module (transfer route), b GaAs/Si NW tandem module (direct growth route), and c incumbent technology single-Si module. Different colors represent data adopted from ecoinvent 3.4 (green color) and up-scaled lab processes for the two production routes (blue color). The detailed up-scaled lab system processes are provided in the Supplementary material S1 and S2 growth and the epitaxial lift-off, as well as the up-scaling description are summarized in Table 1. A detailed discussion on the up-scaling is provided in the Supplementary material S3. The detailed inventory with the up-scaled unit process data is provided in the Supplementary material S4.

\subsubsection{Direct growth route up-scaling}

In this route, the GaAs NWs grow directly on a Si substrate. First, a $\mathrm{SiO}_{2}$ layer is deposited on top of silicon and then $\mathrm{SiO}_{2}$ nanotubes are developed to guide the growth of the NWs on top of silicon. This manufacturing route contains many process steps as described in Supplementary material S2. The specific direct growth route processes for the $\mathrm{SiO}_{2}$ layer deposition, the patterning and $\mathrm{SiO}_{2}$ nanotube formation and the growth of NWs, as well as the description of the up-scaling are summarized in Table 2. A discussion regarding the up-scaling assumptions for each process is provided in the Supplementary material S3. The inventory with the upscaled unit process data is provided in the Supplementary material S5. Finally, the epitaxial processes in both routes require an input of trimethyl-gallium. The trimethyl- 
Table 1 Transfer route processes and up-scaling description

\begin{tabular}{|c|c|c|}
\hline Process - transfer route & (Proxy) technology for up-scaling & Source \\
\hline $\begin{array}{l}\text { Coating, drying, and optical lithography: coating the GaAs } \\
\text { substrate with an organic resist and then } \\
\text { photo-patterning } \\
\text { the substrate }\end{array}$ & $\begin{array}{l}\text { Coating, drying, and optical lithography: coating a copper substrate } \\
\text { with an organic resist and then photo-patterning the substrate. } \\
\text { This is the same process that is used for the development of a } \\
\text { power electronic inverter. }\end{array}$ & Nordelöf 2018 \\
\hline Electroplating: plating gold on a GaAs substrate & Electroplating: plating gold on a nickel substrate & Nordelöf 2018 \\
\hline Wet etching: etch away the organic resist layer & Wet etching: energy from a wet etching tool for single-Si cells & Louwen et al. 2015 \\
\hline \multirow[t]{3}{*}{$\begin{array}{l}\text { MOVPE or MOCVD ( } 3 \text { scenarios): deposition of } \\
\text { III-V materials (nanowires) }\end{array}$} & $\begin{array}{l}\text { Baseline: large CVD: energy from a CVD tool for deposition of } \\
\text { silicon }\end{array}$ & $\begin{array}{l}\text { Personal } \\
\text { communication- } \\
\text { Fraunhofer ISE }\end{array}$ \\
\hline & $\begin{array}{l}\text { Scenario 1: MOCVD: energy from an MOCVD tool for deposition } \\
\text { of III-V materials (LED production (Veeco 2018)) }\end{array}$ & Smith 2018 \\
\hline & $\begin{array}{l}\text { Scenario 2: MOCVD: energy from an MOCVD tool for deposition } \\
\text { of III-V materials (largest available tool for solar cells). }\end{array}$ & $\begin{array}{l}\text { Personal } \\
\text { communication- } \\
\text { EU SiTaSol }{ }^{1}\end{array}$ \\
\hline $\begin{array}{l}\text { Epitaxial lift-off (ELO): peel-off III-V layer (nanowires). } \\
\text { Then clean and re-polish the GaAs wafer for reuse }\end{array}$ & $\begin{array}{l}\text { Epitaxial lift-off: peel-off III-V layer. Then clean and re-polish the } \\
\text { GaAs wafer for reuse. Process used in multi-junction solar cells. }\end{array}$ & Smith 2018 \\
\hline
\end{tabular}

${ }^{1}$ https://sitasol.com/

compounds production is provided in the Supporting material S7 with data from Smith (2018).

\subsection{Life cycle assessment-goal and scope definition}

Two ex-ante LCAs for the production of up-scaled GaAs/ Si nanowire solar modules - one for each of the two different manufacturing routes-have been performed.
Thereupon, an LCA for the production of the commercial single-Si modules was performed. No optimizations have been assumed for the production of the incumbent single$\mathrm{Si}$ modules. Any optimizations for single-Si modules would have also been applicable to the GaAs/Si modules, since the underlying single-Si technology is assumed to be the same.

Table 2 Direct growth route processes and up-scaling description

\begin{tabular}{|c|c|c|}
\hline Process - direct growth route & (Proxy) technology for up-scaling & - \\
\hline $\begin{array}{l}\text { Low pressure chemical vapor deposition (LPCVD): } \\
\text { deposition of } \mathrm{SiO}_{2}\end{array}$ & $\begin{array}{l}\text { Chemical vapor deposition: energy from a } \\
\text { CVD tool for deposition of silicon }\end{array}$ & $\begin{array}{l}\text { Personal } \\
\text { communication- } \\
\text { Fraunhofer ISE }\end{array}$ \\
\hline $\begin{array}{l}\text { Coating, drying, and optical lithography: coating } \\
\text { the GaAs substrate with an organic resist and } \\
\text { then photo-patterning the substrate }\end{array}$ & $\begin{array}{l}\text { Coating, drying, and optical lithography: } \\
\text { coating a copper substrate with an organic } \\
\text { resist and then photo-patterning the substrate. } \\
\text { This is the same process that is used for the } \\
\text { development of a power electronic inverter. }\end{array}$ & Nordelöf 2018 \\
\hline \multirow[t]{2}{*}{$\begin{array}{l}\text { Reactive ion etching, } \mathrm{O}_{2} \text { plasma, inductively coupled plasma } \\
\text { ( } 2 \text { scenarios): plasma-based dry etching processes }\end{array}$} & $\begin{array}{l}\text { Baseline: dry etching tool: energy from an atmospheric } \\
\text { dry etching tool for silicon }\end{array}$ & Andersen et al. 2014 \\
\hline & $\begin{array}{l}\text { Scenario 1: PECVD: energy from a plasma enhanced } \\
\text { chemical vapor deposition (PECVD) tool for silicon }\end{array}$ & Louwen et al. 2015 \\
\hline $\begin{array}{l}\text { Acid-based cleaning, HF etching, acetone and IPA, TMAH } \\
\text { etching: wet etching processes }\end{array}$ & $\begin{array}{l}\text { Wet etching: energy from a wet etching/cleaning tool for } \\
\text { single-Si cells }\end{array}$ & Louwen et al. 2015 \\
\hline \multirow[t]{3}{*}{$\begin{array}{l}\text { MOVPE or MOCVD ( } 3 \text { scenarios): deposition } \\
\text { of III-V materials (nanowires) }\end{array}$} & $\begin{array}{l}\text { Baseline: large CVD: energy from a CVD tool for } \\
\text { deposition of silicon }\end{array}$ & $\begin{array}{l}\text { Personal } \\
\quad \text { communication- } \\
\text { Fraunhofer ISE }\end{array}$ \\
\hline & $\begin{array}{l}\text { Scenario 1: MOCVD: energy from an MOCVD tool for } \\
\text { deposition of III-V materials (LED production } \\
\text { (Veeco 2018)) }\end{array}$ & Smith 2018 \\
\hline & $\begin{array}{l}\text { Scenario 2: MOCVD: energy from an MOCVD tool for } \\
\text { deposition of III-V materials (largest available tool for } \\
\text { solar cells) }\end{array}$ & $\begin{array}{l}\text { Personal } \\
\text { communication- } \\
\text { EU SiTaSol }\end{array}$ \\
\hline
\end{tabular}


The life cycle environmental impact of the GaAs/Si modules is compared with that of the reference single-Si modules. A number of optimization scenarios are explored for the GaAs/Si module to reduce its environmental impact. The functional unit used is $1 \mathrm{kWh}$ of electricity production, with the GaAs/Si NW modules and the single-Si module as the alternatives compared. The geographical scope of the study is assumed to be Southern Europe, which is also representative for the global average insolation, resulting in an insolation of $1700 \mathrm{kWh} /\left(\mathrm{m}^{2}\right.$ year) (Frischknecht et al. 2015). The system boundaries for the GaAs/Si NW modules include the raw material extraction, the GaAs and single-Si wafer manufacturing, the growth of NWs, the single-Si cell and module manufacturing, and the operation of the PV system. The system boundaries for the single-Si module include the raw material extraction, the single-Si wafer production, the single-Si cell and module manufacturing, and the operation of the PV system. The solar modules are assumed to operate on slantedroofs. The inverter and balance of system (BOS) components for slanted-roof mounted applications have been taken into account. End-of-life treatment has not been taken into account due to the lack of solar technologies recycling data, as well as due to the lack of nano-specific emission data. The product systems, reference flows, and system boundaries are shown in Fig. 1.

\subsection{Data}

For the GaAs NW top cell manufacturing, in the $\mathrm{GaAs} / \mathrm{Si}$ tandem formation, a combination of data from the literature, the ecoinvent 3.4 database (Wernet et al. 2016), and the NanoTandem project technology partners (EU H2020 NanoTandem 2015) has been used. For the single-Si bottom cell of the GaAs/Si tandem formation, the module manufacturing, and the BOS components, for slanted-roof installations, data from the ecoinvent database have been used. Finally, for the incumbent single-Si module technology, for the single-Si wafer, cell, module, and BOS for slanted roof installations, data from the ecoinvent database have been used. In order to contribute to the reproducibility and transparency of results (Hertwich et al. 2018), detailed inventory data as well as ecoinvent 3.4 process names and calculations are provided in the Supplementary material S4 to S7.

\subsection{Life cycle impact assessment}

For the life cycle impact assessment (LCIA), the CML 2001 impact assessment method is used (Guinée et al. 2002). The impact categories that have been assessed are the following: climate change, land use, acidification, ozone depletion, freshwater, marine, terrestrial ecotoxicity, eutrophication, human toxicity, and photochemical oxidation. The cumulative primary energy demand (CED) has also been assessed. It represents the direct and indirect primary life cycle energy requirements for the production of the different solar technologies. It is the total amount of all the renewable and non-renewable energy inputs (Mohr et al. 2013). The software that has been used in our analysis is the CMLCA 6.0 version (www.cmlca.eu). Furthermore, the latest product environmental footprint (PEF) impact assessment method has also been used. Results are discussed in Sect. 3.1 and included in the Supplementary material S9.

\subsection{Additional parameters}

\subsubsection{Insolation, performance ratio, lifetime, and conversion efficiency}

As discussed above, the functional unit that has been selected in the study is $1 \mathrm{kWh}$ of electricity production from the different solar technologies. In order to calculate the solar module area $^{3}$ that is required per $\mathrm{kWh}$ of electricity production, additional parameters are required. These parameters are the insolation, performance ratio (PR) of the module, lifetime, and conversion efficiency of the module (Monteiro Lunardi et al. 2017). The insolation is assumed to be $1700 \mathrm{kWh} /\left(\mathrm{m}^{2}\right.$ year $)$ (Frischknecht et al. 2015). The performance ratio of today's modules is assumed to be about $85 \%$ (Fraunhofer ISE 2017). The lifetime of the modules is assumed to be 30 years (Fthenakis et al. 2011). Lastly, the conversion efficiency of the single-Si modules has been assumed to be $18 \%$. The average stabilized efficiency for single-Si solar cells in mass production is about 20\% (ITRPV Working Group 2017; ITRPV 2018). For module efficiency, we assume a constant $2 \%$ point cell to module loss (Louwen et al. 2015). The goal of the NanoTandem project is to develop a GaAs/Si NW solar cell with an efficiency beyond $25 \%$. For the up-scaled GaAs/ Si NW modules, an $28 \%$ module efficiency is assumed (personal communication-SOL Voltaics). For the calculation of the module area per $\mathrm{kWh}$ of electricity production, the method described in Monteiro Lunardi et al. (2017) has been used. Calculations are provided in the Supplementary material S8. The parameters and values are summarized in Table 3.

\subsubsection{Energy payback time}

The energy payback time (EPBT) is an important metric that is applied in the solar technologies. It calculates the time (usually in years) that is required for a solar technology to operate in order to generate the amount of energy that has been invested for its production (Celik et al. 2018). To calculate the EPBT, the CED is used together with other parameters:

\footnotetext{
${ }^{3}$ The solar module area is essentially the size of the solar module to produce $1 \mathrm{kWh}$ of electricity. It is dependent to the insolation, conversion efficiency, performance ratio, and lifetime of the module.
} 
Table 3 Overview of all parameters for the baseline scenario for the different solar technologies

\begin{tabular}{llll}
\hline Parameter & Single-Si module & $\begin{array}{l}\text { GaAs/Si module - transfer } \\
\text { route }\end{array}$ & $\begin{array}{l}\text { GaAs/Si module - direct growth } \\
\text { route }\end{array}$ \\
\hline $\begin{array}{l}\text { Conversion } \\
\text { efficiency }\end{array}$ & $18 \%$ & $28 \%$ & $28 \%$ \\
$\begin{array}{l}\text { Insolation } \\
\text { Performance ratio }\end{array}$ & $1700 \mathrm{kWh} /\left(\mathrm{m}^{2}\right.$ year $)$ & $1700 \mathrm{kWh} /\left(\mathrm{m}^{2}\right.$ year $)$ & $1700 \mathrm{kWh} /\left(\mathrm{m}^{2}\right.$ year $)$ \\
$\quad$ (PR) & $85 \%$ & $85 \%$ & $85 \%$ \\
Lifetime & 30 years & 30 years & 30 years \\
Epitaxial tool & - & CVD proxy & CVD proxy \\
GaAs wafer reuse & - & 100 times & - \\
Gold losses & - & No recovery & - \\
Dry etching & - & - & Dry etching of Si proxy \\
\hline
\end{tabular}

the insolation, performance ratio, conversion efficiency of the module, conversion factor from $\mathrm{MJ}$ (primary energy) to $\mathrm{kWh}$, and the average conversion efficiency from energy to electricity for the European electricity grid (Bhandari et al. 2015; Celik et al. 2016)—Supplementary material S8.

\subsubsection{Balance of system components and inverter}

The BOS components and the inverter have been included in our analysis. These data are provided from the ecoinvent database for the production of a 3-kWp (kilowatt-peak) slantedroof installation PV system. The BOS components, which include among others the structural components to mount the PV modules on the roofs, scale proportionally to the area of the solar module (Bobela et al. 2017). Since the tandem module is assumed to have a higher conversion efficiency compared with the single-Si module, it will result in less module area requirements for the production of $1 \mathrm{kWh}$ of electricity, and thus, it will result in less BOS components per $\mathrm{kWh}$ when compared with a single-Si module. On the other hand, the inverter scales proportionally to the electric power of the module (Bobela et al. 2017). Since the inverter input is power related, both the GaAs/Si NW modules and the single-Si module will require the same amount of inverter for $1 \mathrm{kWh}$ of electricity production. The material and energy requirements of the BOS components and the inverter have been calculated and explained in the Supplementary material S8.

\subsection{Scenarios}

The baseline scenario includes the up-scaled processes as described in Tables 1 and 2. In the baseline scenario, the efficiency of the tandem modules is assumed to be $28 \%$ and a large CVD tool for silicon is used as a proxy for the epitaxial (MOVPE) process in both routes. Furthermore, the GaAs wafer is assumed to be reused 100 times (for the transfer route), and a dry etching process is used as a proxy for the RIE, $\mathrm{O}_{2}$ plasma, and ICP processes (for the direct growth route, Table 3).

In addition to the baseline scenario, additional processspecific scenarios are applied to the sensitive MOVPE processes (in both routes) and to the RIE, $\mathrm{O}_{2}$ plasma, and ICP (in the direct growth route). Furthermore, a number of scenarios are explored for further optimization of the tandem technology.

\subsection{Reuse of GaAs wafer (transfer route)}

III-V/Si NW solar cells are quite expensive at the moment due to their early stage of development. Successful commercialization of the technology implies a high reuse rate of the wafer. Five to 10 wafer reuses have already been achieved (Adams et al. 2012; Lee et al. 2012). However, as a baseline case, we assume 100 times reuse of the GaAs wafer. This is considered necessary in order to reduce costs and achieve a cost-competitive technology (Ward et al. 2016; Essig et al. 2017). In addition, a maximum of 500 reuses is also modeled as this can significantly reduce the production costs even further (Woodhouse and Goodrich 2014). We recall that a thick GaAs wafer-like the one we modeled in this study of 625- $\mu \mathrm{m}$ thickness - is necessary in order to achieve a large number of reuses (Woodhouse and Goodrich 2014).

\subsection{Chemical mechanical polishing (transfer route)}

The epitaxial lift-off (ELO) process is used to transfer the GaAs NWs on a silicon wafer. In each ELO step, a CMP step also takes place to re-polish the GaAs wafer in order to be ready for reuse. CMP is also considered a very expensive process, and for that reason, one CMP step follows for each 10 ELO steps in this optimization scenario (Ward et al. 2016; Essig et al. 2017; Abdul et al. 2018). 


\subsection{Gold recovery (transfer route)}

Gold is a strong light absorber, and thus, the gold particles are peeled off after they have been used for the growth of NWs. In our previous study, we identified the use of gold as an important driver for various impact categories (Pallas et al. 2019). In addition, gold use increases the cost of the tandem module (Jafari Jam et al. 2014). Although the use of gold is minimized by the use of the electroplating process (Pallas et al. 2019), a theoretical scenario of $90 \%$ recovery of gold (Shen and Xue 2007; Pati et al. 2016) to be used in the same system is modeled for the peeled-off gold particles.

\subsection{Trifluoromethane $\left(\mathrm{CHF}_{3}\right)$ (direct growth route)}

The use of $\mathrm{CHF}_{3}$ has been identified in our previous study as an important driver of ozone depletion impacts (Pallas et al. 2019). The reduction on $\mathrm{CHF}_{3}$ use that is required to be realized, in order for the ozone depletion impact of the $\mathrm{GaAs} / \mathrm{Si}$ module to breakeven to that of the incumbent technology, will be calculated.

\section{Results}

\subsection{Life cycle impact assessment-baseline scenario}

As mentioned in the previous chapter, we performed an exante LCA of the emerging GaAs/Si NW modules for two different manufacturing routes and compared the impact assessment results with the incumbent single-Si module technology. The characterization results for the baseline scenario, for 10 impact categories, are presented in Table 4.

Table 4 shows that the GaAs/Si NW modules, for both routes, perform better compared with the incumbent technology in all impact categories with one exception. That is with the exception of the ozone depletion impact, which is much higher in the direct growth route. This is caused by the use of $\mathrm{CHF}_{3}$ in the reactive ion etching process. For all other impact categories assessed, the direct growth route performs best. For instance, the impact related to climate change is about $29 \%$ lower for the direct growth route and 23\% lower for the transfer route $\mathrm{GaAs} / \mathrm{Si}$ modules compared with the single-Si modules for the baseline scenario. For the other impact categories, the direct growth route performs between 20 and $30 \%$ better compared with the incumbent technology (with the alreadymentioned exception of the ozone depletion), while the transfer route performs 5 to $24 \%$ better compared with the singe-Si solar modules.

More specifically, within the nano-embedded solar technology in the transfer route, the eutrophication and terrestrial ecotoxicity impacts are 5\% and $9 \%$ better compared with the incumbent technology. This difference is not that high and can be considered comparable with the impact of the single-Si module for these two impact categories. The additional impact comes from the GaAs wafer production and the requirement of gold from the electroplating process in this route. The direct growth route has thus the best overall environmental performance, due to the GaAs substrate-free and gold-free growth of NWs as opposed to the transfer route. The detailed contribution analysis is presented in Sect. 3.3. Finally, the characterization results have also been calculated with the latest PEF impact assessment method. The percentage advantage of the environmental impacts of the tandem technologies compared with the incumbent is similar to that of the CML 2001 method, as presented in Table 4. Results are provided in the Supplementary material S9.

\subsection{Energy payback time}

For the baseline scenario, the EPBT of the $\mathrm{GaAs} / \mathrm{Si}$ nanowire tandem modules are 1.37 and 1.56 years for the direct growth route and the transfer route, respectively. The EPBT for the incumbent single-Si module is 1.84 years. Thus, the $\mathrm{GaAs} / \mathrm{Si}$ technology results in a smaller EPBT compared with the incumbent technology, for both manufacturing routes.

\subsection{Contribution analysis-baseline scenario}

Figure 2 shows the contribution of the processes to all impact categories assessed for the transfer route. We can notice that, for most impact categories assessed, about 80 to $90 \%$ of the impact is due to the single-Si wafer, cell, module, inverter, and BOS components, and the remaining impact is due to the NWspecific processes. In particular, the single-Si wafer is the main driver for acidification (29\% of the total impact), climate change (45\%), land use (35\%), and CED (44\%). The single-Si cell manufacturing is the largest contributor of ozone depletion (38\% of the total impact). The inverter is the main contributor for the eutrophication (33\%), human toxicity (42\%), photochemical oxidation (33\%), and terrestrial ecotoxicity (40\%) impact categories. The BOS components are the main driver of freshwater ecotoxicity (54\%) and marine ecotoxicity (37\%) impacts. Lastly, it is worth noting that the GaAs wafer production and the electroplating process for the gold deposition (within the patterning and gold deposition step in the graph) also show a considerable contribution to some impact categories. For instance, the contribution of the GaAs wafer production to ozone depletion, terrestrial ecotoxicity, and CED (even after the 100 times reuse that is considered in the baseline scenario) is about $11-12 \%$. The contribution of the electroplating process to eutrophication is about $10 \%$, which is due to a very small amount of gold that is required $(169 \mathrm{mg} /$ $\mathrm{m}^{2}$ ). The impact of the production of gold and the related metals that are present in the sulfidic tailings of the gold production activity is a well-known problem of environmental 
Table 4 Characterization results and overview of the baseline scenario parameters for $1 \mathrm{kWh}$ of electricity production by the commercial single-Si module and the prospective $\mathrm{GaAs} / \mathrm{Si}$ modules

\begin{tabular}{|c|c|c|c|c|}
\hline & Incumbent: single-Si module & $\begin{array}{l}\text { Transfer route: } \mathrm{GaAs} / \mathrm{Si} \\
\text { nanowire module }\end{array}$ & $\begin{array}{l}\text { Direct growth route: } \mathrm{GaAs} / \mathrm{Si} \\
\text { nanowire module }\end{array}$ & \\
\hline $\begin{array}{c}\text { Baseline scenario parameters } \\
\text { overview_-benchmarking }\end{array}$ & $\begin{array}{l}\text { Efficiency: } 18 \% \\
\text { Insolation: } 1700 \mathrm{kWh} /\left(\mathrm{m}^{2} \text { year }\right) \\
\text { PR: } 85 \%\end{array}$ & $\begin{array}{l}\text { Efficiency: } 28 \% \\
\text { Insolation: } 1700 \mathrm{kWh} /\left(\mathrm{m}^{2} \text { year }\right) \\
\text { PR: } 85 \% \\
\text { MOVPE: CVD proxy } \\
\text { Wafer reuse: } 100 \text { times } \\
\text { Gold: no recovery } \\
\text { CMP: in each ELO step }\end{array}$ & $\begin{array}{l}\text { Efficiency: } 28 \% \\
\text { Insolation: } 1700 \mathrm{kWh} / \\
\quad\left(\mathrm{m}^{2} \text { year) }\right. \\
\text { PR: } 85 \% \\
\text { MOVPE: CVD proxy } \\
\text { Dry etching: atmospheric }\end{array}$ & \\
\hline Impact categories & \multicolumn{3}{|c|}{ Characterization results (improvement compared with incumbent \%) } & Unit \\
\hline Climate change & $4.84 \mathrm{E}-02$ & $3.74 \mathrm{E}-02(23 \%)$ & $3.45 \mathrm{E}-02(29 \%)$ & $\mathrm{kg} \mathrm{CO}_{2}$-eq \\
\hline Acidification & $3.06 \mathrm{E}-04$ & $2.47 \mathrm{E}-04(19 \%)$ & $2.30 \mathrm{E}-04(25 \%)$ & $\mathrm{kg} \mathrm{SO}_{2}$-eq \\
\hline Eutrophication & $1.57 \mathrm{E}-04$ & $1.49 \mathrm{E}-04(5 \%)$ & $1.23 \mathrm{E}-04(22 \%)$ & $\mathrm{kg} \mathrm{PO}_{4}$-eq \\
\hline Land use & $2.60 \mathrm{E}-03$ & $2.21 \mathrm{E}-03(15 \%)$ & $1.97 \mathrm{E}-03(24 \%)$ & $\mathrm{m} 2 \mathrm{a}$ \\
\hline Ozone depletion & $4.06 \mathrm{E}-09$ & $3.23 \mathrm{E}-09(20 \%)$ & $8.51 \mathrm{E}-08(-2000 \%)$ & kg CFC-11-eq \\
\hline Terrestrial ecotoxicity & $3.05 \mathrm{E}-04$ & $2.78 \mathrm{E}-04(9 \%)$ & $2.43 \mathrm{E}-04(20 \%)$ & $\mathrm{kg} \mathrm{1,4-DCB-eq}$ \\
\hline Marine ecotoxicity & $2.07 \mathrm{E}+02$ & $1.67 \mathrm{E}+02(19 \%)$ & $1.55 \mathrm{E}+02(25 \%)$ & kg 1,4-DCB-eq \\
\hline Freshwater ecotoxicity & $1.03 \mathrm{E}-01$ & $7.84 \mathrm{E}-02(24 \%)$ & $7.20 \mathrm{E}-02(30 \%)$ & kg 1,4-DCB-eq \\
\hline Human toxicity & $1.13 \mathrm{E}-01$ & $9.53 \mathrm{E}-02(16 \%)$ & $8.83 \mathrm{E}-02(22 \%)$ & kg 1,4-DCB-eq \\
\hline Photochemical oxidation & $1.60 \mathrm{E}-05$ & $1.28 \mathrm{E}-05(20 \%)$ & $1.23 \mathrm{E}-05(23 \%)$ & $\mathrm{kg}$ ethylene-eq \\
\hline
\end{tabular}

pollution and human health issues in several countries with gold mining activity (Aitio et al. 2015; Fashola et al. 2016; Nakazawa et al. 2016; Tejeda-Benitez et al. 2016; Akpalu and Normanyo 2017). The use of gold and the GaAs wafer are unique for the transfer manufacturing route-Supplementary material S9.

Moreover, Fig. 2 shows that the BOS and inverter have a significant contribution to (eco)toxicity impacts. For the inverter production, the upstream processes "treatment of sulfidic tailings from copper production" and "primary copper production" are the main contributors to eutrophication, human toxicity, and terrestrial ecotoxicity. For photochemical oxidation, the biggest contributor is the production of capacitors and auxiliaries that are also inputs for the inverter production. For the BOS components, the treatment of scrap copper in a municipal incineration is the main contributor of freshwater ecotoxicity, while for marine ecotoxicity, the biggest contributor is the anode production followed scrap copper treatment. Furthermore, the single-Si cell production requires an input of trichloromethane $\left(\mathrm{CHCl}_{3}\right)$ and chlorodifluoromethane $\left(\mathrm{CHClF}_{2}\right)$, which notably increase the ozone depletion impact. Lastly, the hard coal mine operation and preparation, for the production of electricity, are the biggest contributors of acidification and climate change impacts in the single-Si wafer

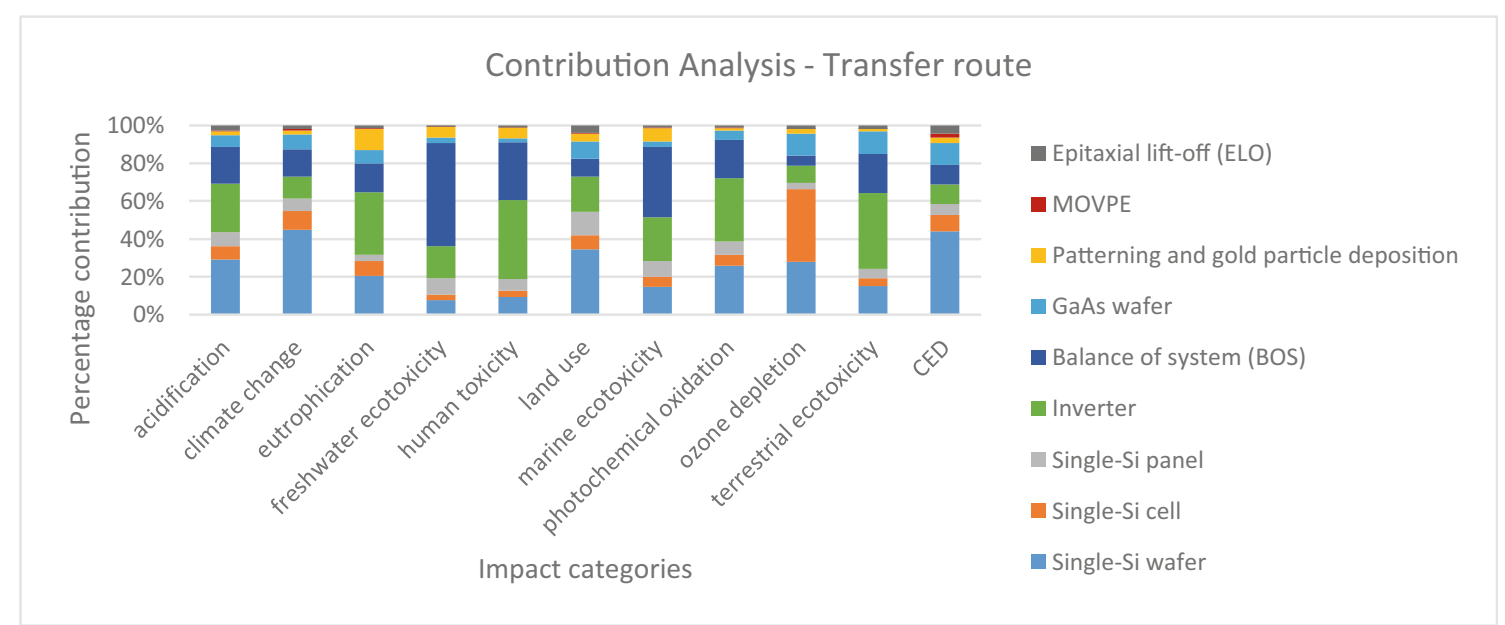

Fig. 2 Results of the contribution analysis for the transfer route. Detailed results for the processes within the "patterning and gold particle deposition" step presented in the graph are provided in the Supplementary material S9 
production process, while the hardwood forestry is the largest contributor for land use.

In the direct growth route, the contribution analysis showed similar results for the major drivers in each impact category as in the transfer route (Fig. 3). We can notice in Fig. 3 that, for most impact categories, about 90 to $95 \%$ of the impact is due to the single-Si wafer, cell, module, inverter, and BOS components (with the exception of the ozone depletion), and the remaining impact is due to the NW-specific processes-see Supplementary material S9. The only difference is in the ozone depletion results, for which the main contributors are the reactive ion etching processes in the $\mathrm{SiO}_{2}$ nanotube formation step due to the use of $\mathrm{CHF}_{3}$.

In particular, $\mathrm{CHF}_{3}$ is produced during the fluorination of $\mathrm{CHCl}_{3}$ which emits tetrachloromethane $\left(\mathrm{CCl}_{4}\right)$ to air, a strong ozone depleting gas (Liang et al. 2017; Pallas et al. 2019). Although $\mathrm{CCl}_{4}$ is a fully controlled substance, emissions are not decreasing fast enough due to various potential sources (Fraser et al. 2014; Lunt et al. 2018; Sherry et al. 2018). Production of $\mathrm{CHF}_{3}$ and hydrofluorocarbons has been identified as sources of ozone-depleting gas emissions (Montzka et al. 2011; Han et al. 2012; Liang et al. 2017; Sherry et al. 2018).

\subsection{Environmental impact under different scenarios}

In the baseline scenario, for both routes, we have considered a CVD tool for silicon as a proxy for up-scaling the MOVPE process. This tool can handle about $7200 \times 8$-in. wafers per hour. Furthermore, we assumed that a dry etching tool for silicon is used as a proxy for up-scaling the RIE, $\mathrm{O}_{2}$ plasma, and ICP process of the direct growth route. To analyze the effects of changes in the energy inputs of the assumed upscaled processes to the impact assessment results, we performed a scenario analysis, including a worst-case scenario.
In particular, the energy consumption of two additional tools is modeled for the MOVPE process in both routes. First, the energy consumption of a proxy MOCVD tool for III-V material deposition for LED production has been modeled (this tool can handle $124 \times 4$-in. wafers per run). Secondly, the energy consumption of a current MOCVD tool for III-V material deposition for solar cell production has been modeled (worst-case scenario - this tool can handle $37 \times 4$-in. wafers per run).

In addition, for the direct growth route, the energy consumption of a proxy PECVD tool has been modeled for the plasma-based etching processes RIE, $\mathrm{O}_{2}$ plasma, and ICP (worst-case scenario). Table 5 summarizes the energy input values of the different tools. Additional information is provided in the Supplementary material S3. The results of the scenario analysis are shown in Fig. 4.

Figure 4 shows the results under the different scenarios for two selected impact categories (results for all impact categories are provided in the Supplementary material S10). The results show that the climate change impact of the GaAs/Si NW module is lower compared with the single-Si module, in all scenarios assessed, for both manufacturing routes. In particular, even in the worstcase scenario, in which the energy parameter of the epitaxial process is increased from $0.68 \mathrm{kWh} / \mathrm{m}^{2}$ (baseline scenario) to $213 \mathrm{kWh} / \mathrm{m}^{2}$ (scenario 2: worst-case scenario), the tandem technology performs better/comparable with the incumbent. For eutrophication, the GaAs/Si module performs worse/comparable with the incumbent, in the worst-case scenario, for the transfer route only. The reason is that the eutrophication impact in the transfer route is already at the same level as the incumbent in the baseline scenario, due to the use of gold. However, the eutrophication impact of the direct growth route is still better/ comparable with the incumbent even in the worst-case scenario.

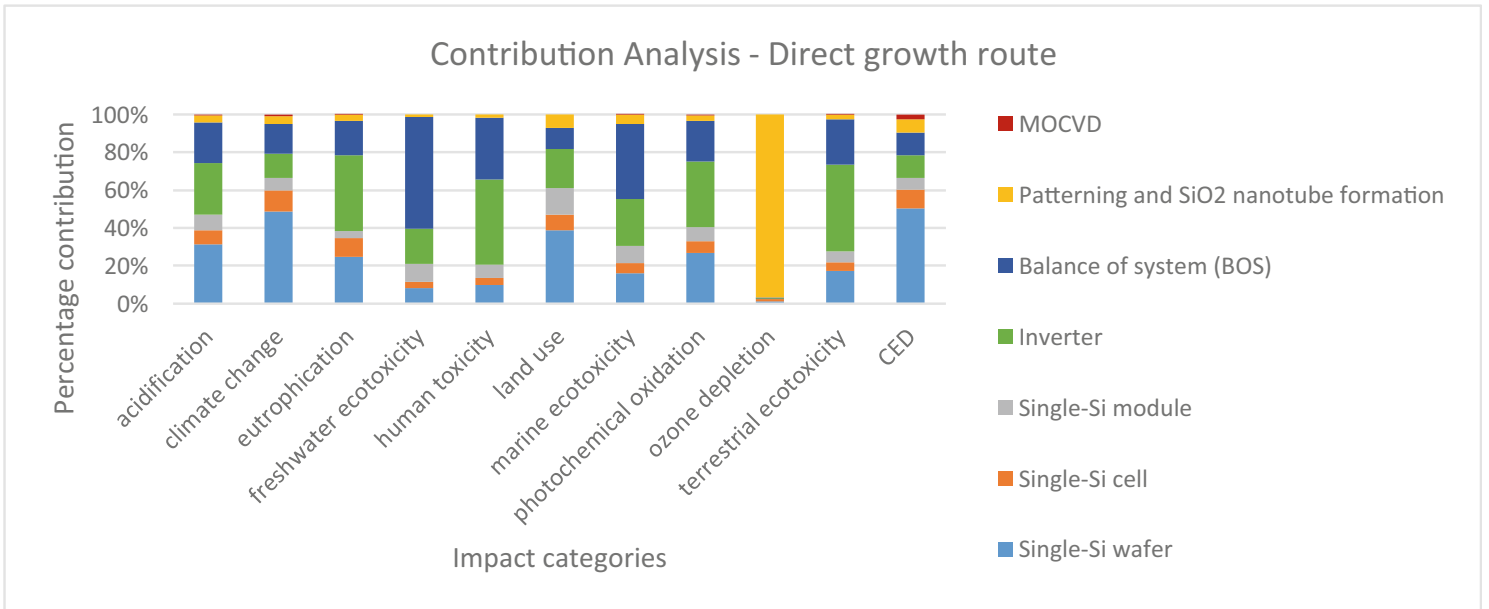

Fig. 3 Contribution analysis for the direct growth route. The detailed results for the processes within the "patterning and $\mathrm{SiO}_{2}$ nanotube formation" step presented in the graph are provided in the Supplementary material S9 
Table 5 Overview of energy input values of the different proxy technologies examined in the scenario analysis

\begin{tabular}{|c|c|c|c|c|}
\hline Process & Baseline scenario & $\begin{array}{l}\text { Scenario } 1 \text { (both } \\
\text { routes) }\end{array}$ & Scenario 2 (both routes) & $\begin{array}{l}\text { Scenario } 3 \text { (direct growth } \\
\text { route only) }\end{array}$ \\
\hline MOVPE — both routes & $\begin{array}{l}\text { CVD-Si proxy: } \\
0.68 \mathrm{kWh} / \mathrm{m}^{2}\end{array}$ & $\begin{array}{l}\text { MOCVD-Led } \\
\text { proxy: } \\
30 \mathrm{kWh} / \mathrm{m}^{2}\end{array}$ & $\begin{array}{l}\text { MOCVD-Solar: } \\
213 \mathrm{kWh} / \mathrm{m}^{2} \text { (worst } \\
\text { case) }\end{array}$ & - \\
\hline $\begin{array}{l}\text { RIE } 1, \mathrm{O}_{2} \text { plasma, ICP ( } 3 \text { consecutive } \\
\text { processes) - direct growth route }\end{array}$ & $\begin{array}{l}\text { Dry-etching Si proxy } \\
5.34 \mathrm{kWh} / \mathrm{m}^{2}\end{array}$ & - & - & $\begin{array}{l}\text { Plasma (PECVD) proxy: } \\
22.8 \mathrm{kWh} / \mathrm{m}^{2} \text { (worst case) }\end{array}$ \\
\hline RIE 2-direct growth route & $\begin{array}{l}\text { Dry-etching Si proxy: } \\
1.78 \mathrm{kWh} / \mathrm{m}^{2}\end{array}$ & - & - & $\begin{array}{l}\text { Plasma (PECVD) proxy: } \\
3.4 \mathrm{kWh} / \mathrm{m}^{2} \text { (worst case) }\end{array}$ \\
\hline
\end{tabular}

Finally, for the additional scenario in the direct growth route, in which a plasma-based process is modeled as a proxy for the dry etching processes, there is only a minor increase for all impact categories.

In general, for most impact categories assessed, the two nano-embedded technologies perform better or comparable with the incumbent technology, even in the worst-case scenario in which the energy of a current energy-intensive III-V MOCVD tool for solar cells is modeled. That is true only if the assumptions for the different parameters, as presented in Table 3, are realized. The only exception is the category of land use impacts in the worst-case scenario, in which the single-Si module performs better than both nano-based routes, due to the additional land required for the increased electricity requirements. Lastly, for the direct growth route, the EPBT is 1.9 years when the worst-case scenarios are applied (scenarios 2 and 3). The result can be considered comparable with the EPBT of 1.84 years of the single-Si module.

\subsection{Impact reduction scenarios for further optimization of the transfer route-benchmarking}

The nano-embedded technology performs better or at least comparable in most impact categories in all scenarios.
However, with the application of various impact reduction scenarios, we can achieve even better performances for the up-scaled GaAs/Si tandem technologies. The results of the application of the different scenarios (Sect. 2.7) for the transfer route are presented in Fig. 5.

\subsection{Transfer route}

\subsubsection{Recycling of gold}

As already discussed, there is the requirement of the deposition of gold particles through the electroplating process in the transfer route. The role of the gold particles is to assist the growth of NWs in the MOVPE reactor. However, the gold particles will not be part of the solar cell, and thus, they are peeled off and disposed. The amount of gold required per $\mathrm{m}^{2}$ of module is very small-i.e., $1.69 \mathrm{E}-4 \mathrm{~kg} / \mathrm{m}^{2}$ or $169 \mathrm{mg} / \mathrm{m}^{2}$. Even though the quantity required is very small, it has a considerable impact on eutrophication, human toxicity, and marine toxicity impacts (as we showed earlier in Fig. 2). In this scenario, we have assumed a $90 \%$ recovery of the gold. This assumption reduces the eutrophication impact by $9.4 \%$, the marine ecotoxicity impact by $6 \%$, and the human toxicity impact by $5 \%$ (Fig. 5).
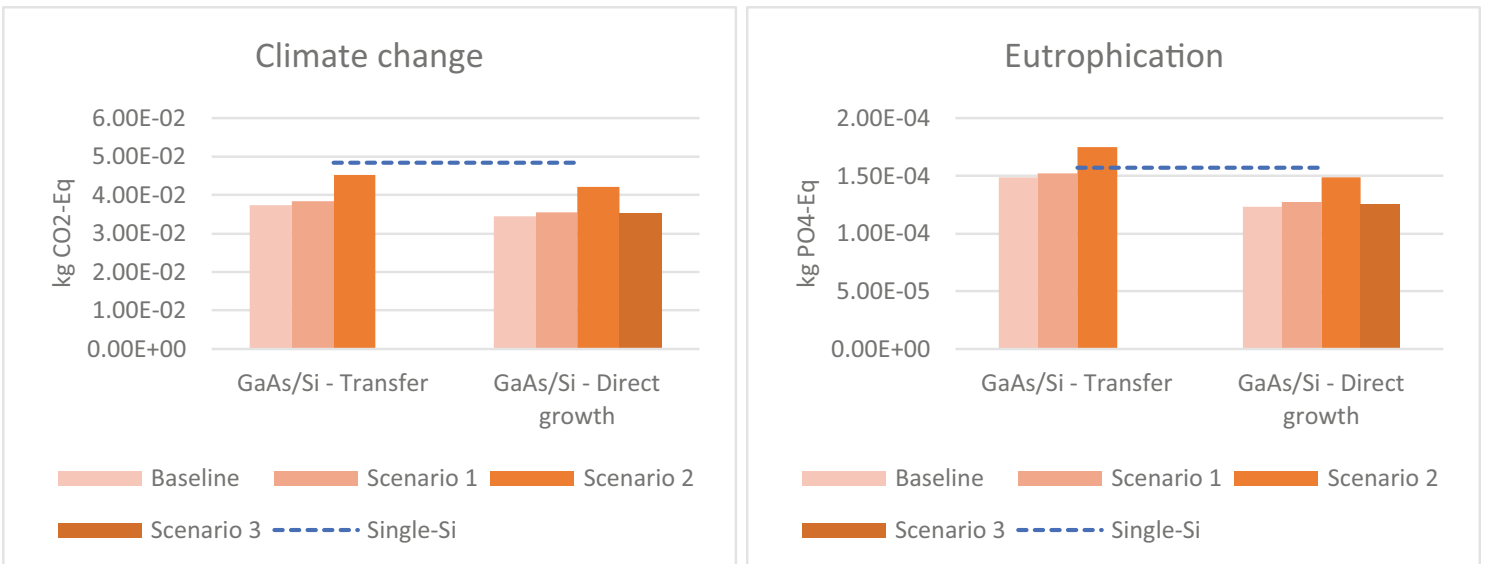

Fig. 4 Climate change and eutrophication impact results under the different scenarios for the transfer and the direct growth route. The vertical dashed blue line shows the single-Si module impact 


\subsubsection{Reuse of GaAs substrate}

It is assumed in the baseline scenario that the wafer is reused 100 times. We have also modeled the case in which the wafer is reused 500 times. This might be necessary for the costcompetitive commercialization of the technology, as described in Sect. 2. Terrestrial ecotoxicity is improved by 9.3\% compared with the baseline scenario, followed by ozone depletion (9\%), CED (9\%), land use (7.2\%), and climate change $(6.7 \%)$, followed by smaller improvements for the other impact categories (Fig. 5). We should also notice that further reuse of the wafer (above 500 times) does not offer any further considerable improvement in the overall impact (Supplementary material S11).

\subsubsection{Chemical mechanical polishing every 10 steps}

The CMP step is an essential step of the ELO process, in which the GaAs substrate is cleaned and re-polished in order to be reused. Technological improvement can potentially offer one CMP step for each 10 ELO steps, as described in Sect. 2. This does not result in a considerable change. Minor improvements can be found for the land use impact (3.6\%), followed by CED (2.7\%) and eutrophication (2.2\%) (Fig. 5).

Lastly, Fig. 5 shows that the biggest cumulative improvement can be achieved for eutrophication (about 17\%) followed by CED, land use, ozone depletion, and terrestrial ecotoxicity (about 12\%). Climate change improves about $9 \%$ when all three impact reduction scenarios achieved.

\subsubsection{Direct growth route}

We recall that the direct growth route of the $\mathrm{GaAs} / \mathrm{Si}$ module performs better compared with the single-Si module in all impact categories assessed but one, ozone depletion. In order for the new technology to breakeven with a single-Si technology, the use of the $\mathrm{CHF}_{3}$ by the reactive ion etching processes needs to be reduced by more than $98 \%$. This essentially means that the use of $\mathrm{CHF}_{3}$ needs to be eliminated or at least minimized, if the direct growth route is to be superior in all impact categories assessed. Lastly, if all optimizations are achieved, then the two manufacturing routes - the transfer and direct growth route-breakeven in most impact categories.

\section{Discussion}

\subsection{Overall performance throughout the life cycle}

In this study, we performed an ex-ante LCA for the production of the emerging GaAs/Si tandem nanowire modules for two different production routes - the transfer and direct growth route - and we compared the environmental performance of the emerging nano-embedded solar technology with the commercial single-Si technology. For the baseline scenario and if all the parameter assumptions are realized, both manufacturing routes perform better compared with the incumbent singleSi technology and result in a lower EPBT. For the direct growth route, more than $90 \%$ of the impact is due to the single-Si wafer, cell, module, inverter, and BOS manufacturing, and less than $10 \%$ is due to $\mathrm{SiO}_{2}$ template formation and the NW growth (Fig. 3). This additional $10 \%$ burden of the NW production is compensated by the higher efficiency that the GaAs/Si module can achieve. Similarly, for the transfer route, about $80 \%$ of the impact is due to the module and operation components and about $20 \%$ is due to the GaAs substrate, gold particle deposition, and the NW growth (Fig. 2). Again, this additional $20 \%$ burden of the nano-embedded

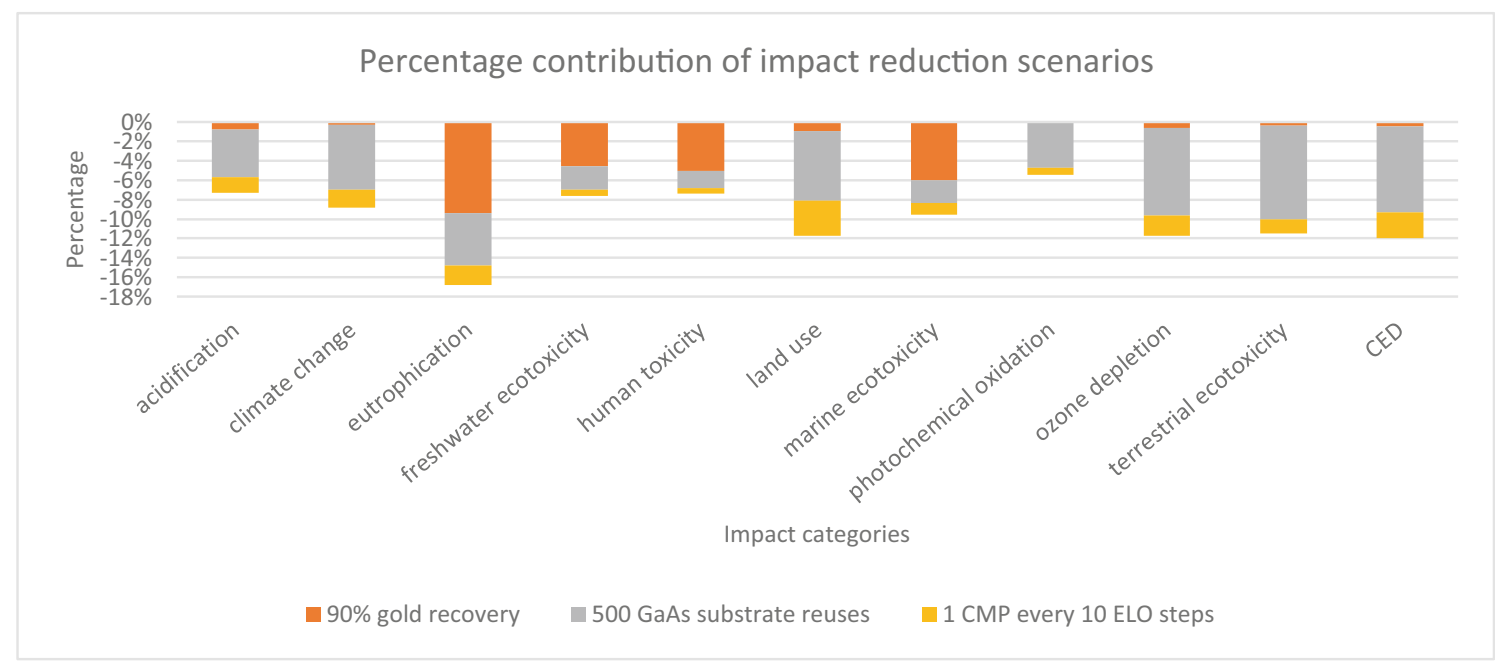

Fig. 5 Percentage contribution improvement under different optimization scenarios of the transfer route. See the Supplementary material S10 for more details 
technology is compensated by the higher efficiency that the $\mathrm{GaAs} / \mathrm{Si}$ module can achieve.

\subsection{Area-related and power-related components}

In the results presented in the contribution analysis earlier (Figs. 2 and 3), it is shown that the single-Si wafer is the largest driver for acidification, climate change, land use, and $\mathrm{CED}$, and the balance of system components are the largest drivers of marine and freshwater ecotoxicity. Since the GaAs/ $\mathrm{Si}$ nanowire tandem technology uses a single-Si wafer as a bottom cell, the higher efficiency the tandem technology can achieve compared with the single-Si technologies, the less wafer area it will require per $\mathrm{kWh}$ of electricity production. Furthermore, the BOS components are also area-related components. Again, the higher efficiency that the tandem technology can achieve compared with the incumbent, the less BOS components installation will be required per $\mathrm{kWh}$ of electricity production. This relationship between area-related components and efficiency leads to reductions in the aforementioned impacts for the tandem technology. The savings that are achieved in the impacts of the area-related components provide room to the tandem technology to compensate for the additional impacts of the NW growth.

Finally, the inverter is a power-related component of the PV system. Since the functional unit selected is $1 \mathrm{kWh}$ of electricity production, all alternatives compared will have the same inverter amount as input. The inverter is the biggest contributor of eutrophication, human toxicity, photochemical oxidation, and terrestrial ecotoxicity.

\subsection{Hotspots of concern}

Gold and $\mathrm{CHF}_{3}$ are important contributors to the overall impact of the up-scaled nano-embedded technology. This is in line with the results of the LCA of the NW-based technology at the lab scale (Pallas et al. 2019). In the case of $\mathrm{CHF}_{3}$, we showed that minimization of the material is required to improve the ozone depletion impact of the direct growth route, for instance by exploring fluorine-free etching materials (Abdolahad et al. 2010). Finally, the impact of the GaAs wafer is quite significant for some impact categories, even after 100 times of reuse in the baseline scenario. A maximum of 500 reuses was modeled, and we showed that after 500 reuses there is no significant impact reduction anymore.

\subsection{Scenario analysis}

The scenario analysis showed that, even in the worst-case scenario, the GaAs/Si module performs better or comparable with commercial single-Si modules. Furthermore, the III-V solar technology can gain from synergies from the fast development of other technologies, like the LED production. We showed that a new MOCVD tool for III-V material deposition for LED production can handle 124 wafers per run while the MOCVD tool for solar technologies can handle 37 wafers per run.

For the baseline scenario, we have modeled the energy of a large CVD tool for silicon and used that as a proxy for up-scaling. This tool can handle $7200 \times 8$-in. wafers per hour. Although such a large tool has not been commercialized yet for III-V materials, there is a new highthroughput and high-yielding process from SOL Voltaics, called Aerotaxy (Heurlin et al. 2012; Borgström et al. 2018; SolVoltaics 2018) that can soon offer costcompetitive $\mathrm{GaAs} / \mathrm{Si} \mathrm{NW}$ tandem solar cells. In particular, III-V epitaxial tools can have a deposition rate close to $60 \mu \mathrm{m} / \mathrm{h}$ in the short term (Essig et al. 2017), while the large CVD tool for silicon that we modeled in our baseline scenario has a deposition rate of $3-10 \mu \mathrm{m} / \mathrm{min}$ (personal communication-Fraunhofer ISE). The new Aerotaxy process, however, can offer a deposition rate of $1 \mu \mathrm{m} / \mathrm{s}$ or $60 \mu \mathrm{m} / \mathrm{min}$ (Yang et al. 2015; Barrigon et al. 2017), which offers a very high throughput even compared with commercial CVD tools for silicon. Due to this high throughput, the Aerotaxy process is likely to offer a similar performance to existing silicon deposition tools. Thus, the selection of a large CVD tool for silicon in the baseline scenario as a proxy for up-scaling the epitaxial process can be considered realistic, when we take these recent developments into account.

\subsection{Toxicity data}

Nano-specific toxicity has not been considered in this study due to the lack of characterization factors. In a previous study, we have shown that studies on LCA of nanotechnologies, for various sectors of the economy, also do not consider nanospecific emissions due to lack of relevant data (Pallas et al. 2018). Toxicity of nanomaterials can be affected by many factors (for example, different shapes and dimensions of nanowires can have a significant effect on the toxicity of the materials), and nanotoxicity is still an emerging field of research. In the case of the nanowire-based solar cells, nanowires will be well bonded into the silicon substrate and will also be encapsulated within glass in the module. Thus, emissions of nanomaterials should be considered only at the end of life of the solar technology (which is out of the scope of this study). Since the underlying technology of the nanowire-based solar module and the single-Si module is the same, the only difference between the two technologies compared is the nanowire layer. Successful treatment of the nano-layer at the end of life of the technology, by etching and recovering/treatment of the nanomaterials to eliminate emissions, will be of high importance. 


\section{Conclusions}

This ex-ante LCA study can be also seen as a benchmark LCA for the improvements that need to be achieved for the emerging technology to perform better compared with the incumbent. Our benchmark is thus a $28 \%$ efficient $\mathrm{GaAs} / \mathrm{Si}$ nanowire tandem module and at least 100 times GaAs substrate reuses for the transfer route. The incumbent technology is an $18 \%$ efficient single-Si module (that is a $10 \%$ efficiency difference between the emerging technology and the incumbent). The insolation is assumed to be $1700 \mathrm{kWh} /\left(\mathrm{m}^{2}\right.$ year $)$, and a performance ratio of $85 \%$ is applied to all technologies assessed.

Either under these conditions only or as a minimum, even in the worst-case scenario in which the energy consumption of a current epitaxial tool is modeled, the GaAs/Si modules perform better or comparable with single-Si modules for most impact categories assessed, as we showed in Sect. 4.4. Furthermore, in the baseline scenario in which we modeled the energy consumption of a CVD tool for silicon, the transfer route performs 5 to $24 \%$ better and the direct growth route performs 20 to $30 \%$ better compared with single-Si modules (except for ozone depletion).

Our results show that the direct growth route has the best potential for up-scaling, mainly due to the III-V substrate-free and gold-free growth. The use of $\mathrm{CHF}_{3}$ however needs to be minimized if the direct growth route is going to offer a superior performance in all impact categories. On the other hand, for the transfer route, if technological innovations take place, the III-V substrate can be reused by about 500 times, the use of gold is minimized, and one CMP step is considered for each 10 ELO steps, then the transfer route can offer a similar performance to the direct growth route. Finally, the energy consumption of the epitaxial process is of high importance for a successful commercialization of the emerging technology. Improvements in the solar cell industry are expected, as well as benefits from improvements in other sectors, like the electronics sector for LED production. Lastly, the Aerotaxy process, that we described earlier, can offer a high-throughput process and an unprecedented rate of nanowire growth, potentially resulting in a similar or better performance to existing large silicon deposition tools.

The limitation of this study is the non-inclusion of the endof-life treatment in the analysis, specifically the non-inclusion of nano-specific emissions due to the lack of relevant data. The treatment of nanowaste at the end of life of the technology and the potential recovery/treatment of nanomaterials to avoid emissions can be of high importance.

Last but not least, it is noted that all above conclusions are "if-then" conclusions. Only if the assumptions we made appear to be valid or are realized, then the conclusions as drawn above are valid. The conclusions are thus scenario-based conclusions and not yet performancebased conclusions. The LCA results of this study can only be used as a benchmark indicating the improvements needed for the emerging technology to eventually perform better compared with the incumbent technology. Finally, in addition to the environmental performance benchmark that was explored in this study, significant improvements in the cost of the production of the emerging technology need to be realized before the technology can become commercial.

Acknowledgments We thank the partners in the Nano-Tandem consortium who were willing to share their data and technological insights. Funding information This project has received funding from the European Union's Horizon 2020 Research and Innovation Program under the grant agreement no. 641023 .

\section{Compliance with ethical standards}

Conflict of interest The authors declare that they have no conflict of interest.

Open Access This article is licensed under a Creative Commons Attribution 4.0 International License, which permits use, sharing, adaptation, distribution and reproduction in any medium or format, as long as you give appropriate credit to the original author(s) and the source, provide a link to the Creative Commons licence, and indicate if changes were made. The images or other third party material in this article are included in the article's Creative Commons licence, unless indicated otherwise in a credit line to the material. If material is not included in the article's Creative Commons licence and your intended use is not permitted by statutory regulation or exceeds the permitted use, you will need to obtain permission directly from the copyright holder. To view a copy of this licence, visit http://creativecommons.org/licenses/by/4.0/.

\section{References}

Abdolahad M, Nilchi JN, Mohajerzadeh S (2010) Fluorine-free highresolution selective plasma etching of silicon-oxide layers on silicon substrates. J Phys D Appl Phys 43:395402

Abdul Hadi S, Fitzgerald EA, Griffiths S, Nayfeh A (2018) III-V/Si dual junction solar cell at scale: manufacturing cost estimates for step-cell based technology. J Renew Sustain Ener 10:15905

Adams J, Elarde V, Hains A, et al (2012) Demonstration of multiple substrate reuses for inverted metamorphic solar cells. In: 2012 IEEE 38th photovoltaic specialists conference (PVSC) PART 2. IEEE, pp 1-6

Aitio A, Kiilunen M, Santonen T, Nordberg M (2015) Gold and gold mining. In: Handbook on the Toxicology of Metals. Elsevier, Amsterdam, pp 817-843

Akpalu W, Normanyo AK (2017) Gold mining pollution and the cost of private healthcare: the case of Ghana. Ecol Econ 142:104-112

Almansouri I, Ho-Baillie A, Bremner SP, Green MA (2015) Supercharging silicon solar cell performance by means of multijunction concept. IEEE J Photovolt 5:968-976

Andersen O, Gilpin G, Andrae ASG (2014) Cradle-to-gate life cycle assessment of the dry etching step in the manufacturing of photovoltaic cells. AIMS Energy 2:410-423 
Anttu N, Abrand A, Asoli D, Heurlin M, Åberg I, Samuelson L, Borgström M (2014) Absorption of light in InP nanowire arrays. Nano Res 7:816-823

Arvidsson R, Kushnir D, Sandén B a, Molander S (2014) Prospective life cycle assessment of graphene production by ultrasonication and chemical reduction. Environ Sci Technol 48:4529-4536. https:// doi.org/10.1021/es405338k

Arvidsson R, Tillman A-M, Sandén BA et al (2017) Environmental assessment of emerging technologies: Recommendations for Prospective LCA. J Ind Ecol. https://doi.org/10.1111/jiec.12690

AZO Materials (2014) How metal organic chemical vapor phase deposition (MOCVD) Works. https://www.azom.com/article.aspx? ArticleID=11585. Accessed May 2019

Barrigon E, Hultin O, Lindgren D et al (2017) GaAs nanowire pnjunctions produced by low-cost and high-throughput Aerotaxy. Nano Lett 18:1088-1092

Bhandari KP, Collier JM, Ellingson RJ, Apul DS (2015) Energy payback time (EPBT) and energy return on energy invested (EROI) of solar photovoltaic systems: a systematic review and meta-analysis. Renew Sust Energ Rev 47:133-141

Bobela DC, Gedvilas L, Woodhouse M, Horowitz KAW, Basore PA (2017) Economic competitiveness of III-V on silicon tandem onesun photovoltaic solar modules in favorable future scenarios. Prog Photovolt Res Appl 25:41-48

Borg M, Schmid H, Moselund KE, Signorello G, Gignac L, Bruley J, Breslin C, Das Kanungo P, Werner P, Riel H (2014) Vertical III-V nanowire device integration on Si (100). Nano Lett 14:1914-1920

Borgström MT, Magnusson MH, Dimroth F et al (2018) Towards nanowire tandem junction solar cells on silicon. IEEE J Photovolt 8:733740

Celik I, Song Z, Cimaroli AJ, Yan Y, Heben MJ, Apul D (2016) Life cycle assessment (LCA) of perovskite PV cells projected from lab to fab. Sol Energy Mater Sol Cells 156:157-169

Celik I, Mason BE, Phillips AB, Heben MJ, Apul D (2017) Environmental impacts from photovoltaic solar cells made with single walled carbon nanotubes. Environ Sci Technol 51:4722-4732

Celik I, Philips AB, Song Z, Yan Y, Ellingson RJ, Heben MJ, Apul D (2018) Energy payback time (EPBT) and energy return on energy invested (EROI) of perovskite tandem photovoltaic solar cells. IEEE J Photovolt 8:305-309

Chiu PT, Law DC, Woo RL, et al (2014) 35.8\% space and 38.8\% terrestrial 5J direct bonded cells. In: 2014 IEEE 40th photovoltaic specialist conference (PVSC). IEEE, pp 11-13

Cucurachi S, van der Giesen C, Guinée J (2018) Ex-ante LCA of emerging technologies. Procedia CIRP 69:463-468

Essig S, Allebé C, Remo T et al (2017) Raising the one-sun conversion efficiency of III-V/Si solar cells to $32.8 \%$ for two junctions and $35.9 \%$ for three junctions. Nat. Energy 2:17144

EU H2020 - NanoTandem (2015) EU H2020 - NanoTandem project. https://nano-tandem.ftf.lth.se/

Fashola M, Ngole-Jeme V, Babalola O (2016) Heavy metal pollution from gold mines: environmental effects and bacterial strategies for resistance. Int J Environ Res Public Health 13:1047

Franklin C (2015) Chasing hazards: toxicity, sustainability, and the hazard paradox. Nat Resour Environ 29:39

Fraser PJ, Dunse BL, Manning AJ, Walsh S, Wang RHJ, Krummel PB, Steele LP, Porter LW, Allison C, O'Doherty S, Simmonds PG, Mühle J, Weiss RF, Prinn RG (2014) Australian carbon tetrachloride emissions in a global context. Environ Chem 11:77-88

Fraunhofer ISE (2017) Photovoltaics report. Fraunhofer ISE, Freibg

Frischknecht R, Itten R, Sinha P et al (2015) Life cycle inventories and life cycle assessment of photovoltaic systems. IEA PVPS 12

Fthenakis V, Frischknecht R, Raugei M et al (2011) Methodology guidelines on life cycle assessment of photovoltaic electricity. IEA PVPS 12
Green MA, Hishikawa Y, Dunlop ED et al (2018) Solar cell efficiency tables (version 52). Prog Photovolt 26

Guinée JB, Gorrée M, Heijungs R, et al (2002) Handbook on life cycle assessment. Operational guide to the ISO standards Int $\mathrm{J}$ life cycle Assess 692

Guineé JB, Heijungs R, Vijver MG, Peijnenburg WJGM (2017) Setting the stage for debating the roles of risk assessment and life-cycle assessment of engineered nanomaterials. Nat Nanotechnol 12:727733. https://doi.org/10.1038/NNANO.2017.135

Guinée JB, Cucurachi S, Henriksson PJG, Heijungs R (2018) Digesting the alphabet soup of LCA. Int J Life Cycle Assess 23:1507-1511

Han W, Li Y, Tang H, Liu H (2012) Treatment of the potent greenhouse gas, CHF 3-an overview. J Fluor Chem 140:7-16

Hertwich E, Heeren N, Kuczenski B, Majeau-Bettez G, Myers RJ, Pauliuk S, Stadler K, Lifset R (2018) Nullius in Verba: advancing data transparency in industrial ecology. J Ind Ecol 22:6-17

Heurlin M, Magnusson MH, Lindgren D, Ek M, Wallenberg LR, Deppert K, Samuelson L (2012) Continuous gas-phase synthesis of nanowires with tunable properties. Nature 492:90-94

IEA - Photovoltaic Power Systems Programme (PVPS) (2009) Trends in photovoltaic applications. Survey report of selected IEA countries between 1992 and 2008. Report IEA-PVPS T1-18:2009

IEA - Photovoltaic Power Systems Programme (PVPS) (2017) Trends 2017 in photovoltaic applications. Survey Report of Selected IEA Countries between 1992 and 2016. Report IEA PVPS T1-32:2017. ISBN: 978-3-906042-68-8

IEA - World Energy Outlook (2019) Installed power generation capacity by source in the stated policies scenario, 2000-2040. IEA, Paris https://www.iea.org/data-and-statistics/charts/installed-powergeneration-capacity-by-source-in-the-stated-policies-scenario2000-2040. Accessed May 2020

International Technology Roadmap for Photovoltaic (ITRPV) (2018) International Technology Roadmap for Photovoltaic (ITRPV) 2017 results, Ninth

ITRPV Working Group (2017) International Technology Roadmap for Photovoltaic (ITRPV). 2016 Results

Jafari Jam R, Heurlin M, Jain V et al (2014) III-V nanowire synthesis by use of electrodeposited gold particles. Nano Lett 15:134-138

Jungbluth N, Stucki M, Flury K, et al (2012) Life cycle inventories of photovoltaics. ESU-services ltd, Uster, $\mathrm{CH}$, retrieved from www ESU-services ch

Kim HC, Fthenakis VM (2011) Comparative life-cycle energy payback analysis of multi-junction a-SiGe and nanocrystalline/a-Si modules. Prog Photovolt Res Appl 19:228-239. https://doi.org/10.1002/pip. 990

Klöpffer W, Curran MA, Frankl P, et al (2007) Nanotechnology and life cycle assessment. A systems approach to nanotechnology and the environment: synthesis of results obtained at a workshop Washington, DC 2-3 October 2006. European Commission, DG research, jointly with the Woodrow Wilson International Center for Scholars

Lee K, Zimmerman JD, Xiao X, Sun K, Forrest SR (2012) Reuse of GaAs substrates for epitaxial lift-off by employing protection layers. J Appl Phys 111:33527

Liang Q, Strahan SE, Fleming EL (2017) Concerns for ozone recovery. Science 358:1257 LP-1251258

Louwen A, Sark W, Schropp REI et al (2015) Life-cycle greenhouse gas emissions and energy payback time of current and prospective silicon heterojunction solar cell designs. Prog Photovolt Res Appl 23: 1406-1428

Lunt MF, Park S, Li S et al (2018) Continued emissions of the ozonedepleting substance carbon tetrachloride from eastern Asia. Geophys Res Lett 45:11-423

Meijer A, Huijbregts MAJ, Schermer JJ, Reijnders L (2003) Life-cycle assessment of photovoltaic modules: comparison of $\mathrm{mc}-\mathrm{Si}$, InGaP 
and InGaP/mc-Si solar modules. Prog Photovolt Res Appl 11:275287. https://doi.org/10.1002/pip.489

Mohr NJ, Schermer JJ, Huijbregts MAJ, Meijer A, Reijnders L (2007) Life cycle assessment of thin- film GaAs and GaInP/GaAs solar modules. Prog Photovolt Res Appl 15:163-179. https://doi.org/10. 1002/pip

Mohr NJ, Meijer A, Huijbregts MAJ, Reijnders L (2013) Environmental life cycle assessment of roof-integrated flexible amorphous silicon/ nanocrystalline silicon solar cell laminate. Prog Photovolt Res Appl 21:802-815

Monteiro Lunardi M, Wing Yi Ho-Baillie A, Alvarez-Gaitan JP, Moore S, Corkish R (2017) A life cycle assessment of perovskite/silicon tandem solar cells. Prog Photovolt Res Appl 25:679-695

Montzka SA, Reimann S, Engel A, et al (2011) Scientific assessment of ozone depletion: 2010 - ozone-depleting substances and related chemicals. Glob Ozone Res Monit Proj no 52 - World Meteorol Organ

Nakazawa K, Nagafuchi O, Kawakami T, Inoue T, Yokota K, Serikawa Y, Cyio B, Elvince R (2016) Human health risk assessment of mercury vapor around artisanal small-scale gold mining area, Palu city, Central Sulawesi, Indonesia. Ecotoxicol Environ Saf 124:155-162

Nordelöf A (2018) A scalable life cycle inventory of an automotive power electronic inverter unit — part II: manufacturing processes. Int J Life Cycle Assess:1-18

Otnes G, Borgström MT (2017) Towards high efficiency nanowire solar cells. Nano Today 12:31-45

Pallas G, Peijnenburg W, Guinée J et al (2018) Green and clean: reviewing the justification of claims for nanomaterials from a sustainability point of view. Sustain 10, page 689 10:689. https://doi. org/10.3390/SU10030689

Pallas G, Vijver M, Peijnenburg W, Guinée J (2019) Life cycle assessment of emerging technologies at the lab scale: the case of nanowirebased solar cells. J Ind Ecol 24:193-204. https://doi.org/10.1111/ jiec. 12855

Pati P, McGinnis S, Vikesland PJ (2016) Waste not want not: life cycle implications of gold recovery and recycling from nanowaste. Environ Sci Nano 3:1133-1143

Richter A, Hermle M, Glunz SW (2013) Reassessment of the limiting efficiency for crystalline silicon solar cells. IEEE J Photovolt 3: 1184-1191

Roes AL, Patel MK (2011) Ex-ante environmental assessments of novel technologies-improved caprolactam catalysis and hydrogen storage. J Clean Prod 19:1659-1667. https://doi.org/10.1016/j.jclepro.2011. 05.010

Roes AL, Alsema EA, Blok K, Patel MK (2009) Ex-ante environmental and economic evaluation of polymer photovoltaics. Prog Photovolt Res Appl 17:372-393. https://doi.org/10.1002/pip.891

Rogelj J, Shindell D, Jiang K, et al (2018) Mitigation pathways compatible with $1.5^{\circ} \mathrm{C}$ in the context of sustainable development

Schmid H, Borg M, Moselund K, Gignac L, Breslin CM, Bruley J, Cutaia D, Riel H (2015) Template-assisted selective epitaxy of III-V nanoscale devices for co-planar heterogeneous integration with Si. Appl Phys Lett 106:233101

Șengül H, Theis TL (2011) An environmental impact assessment of quantum dot photovoltaics (QDPV) from raw material acquisition through use. J Clean Prod 19:21-31

Shen YF, Xue WY (2007) Recovery palladium, gold and platinum from hydrochloric acid solution using 2-hydroxy-4-sec-octanoyl diphenyl-ketoxime. Sep Purif Technol 56:278-283

Sherry D, McCulloch A, Liang Q, Reimann S, Newman PA (2018) Current sources of carbon tetrachloride (CCl4) in our atmosphere. Environ Res Lett 13:24004

Smith B (2018) Development and life cycle assessment of advancedconcept III-V multijunction photovoltaics. Rochester institute of technology. Accessed from https://scholarworks.rit.edu/theses/ 9877. Accessed Sept 2018

SolVoltaics (2018) Aerotaxy - the path to low-cost, high-efficiency PV nanowires. https://solvoltaics.com/solar-cells-panelsnanotechnology/aerotaxy-pv-nanowires/

Tejeda-Benitez L, Flegal R, Odigie K, Olivero-Verbel J (2016) Pollution by metals and toxicity assessment using Caenorhabditis elegans in sediments from the Magdalena River, Colombia. Environ Pollut 212:238-250

Tsang MP, Sonnemann GW, Bassani DM (2016) A comparative human health, ecotoxicity, and product environmental assessment on the production of organic and silicon solar cells. Prog Photovolt Res Appl 24:645-655. https://doi.org/10.1002/pip.2704

van der Meulen R, Alsema E (2011) Life-cycle greenhouse gas effects of introducing nano-crystalline materials in thin-film silicon solar cells. Prog Photovolt Res Appl 19:453-463

Veeco (2018) Veeco TurboDisc EPIK 868 MOCVD System for LED Production. https://www.veeco.com/products/turbodisc-epik-868mocvd-system-for-led-production. Accessed Sept 2018

Villares M, Ișildar A, Mendoza Beltran A, Guinee J (2016) Applying an ex-ante life cycle perspective to metal recovery from e-waste using bioleaching. J Clean Prod 129:315-328. https://doi.org/10.1016/j. jclepro.2016.04.066

Villares M, Iș1ldar A, van der Giesen C, Guinée J (2017) Does ex ante application enhance the usefulness of LCA? A case study on an emerging technology for metal recovery from e-waste. Int J Life Cycle Assess 22:1-16. https://doi.org/10.1007/s11367-017-1270-6

Wallentin J, Anttu N, Asoli D et al (2013) InP nanowire array solar cells achieving $13.8 \%$ efficiency by exceeding the ray optics limit. Science 339:1057-1060

Walser T, Demou E, Lang DJ, Hellweg S (2011) Prospective environmental life cycle assessment of nanosilver T-shirts. Environ Sci Technol 45:4570-4578. https://doi.org/10.1021/es2001248

Ward JS, Remo T, Horowitz K, Woodhouse M, Sopori B, VanSant K, Basore P (2016) Techno-economic analysis of three different substrate removal and reuse strategies for III-V solar cells. Prog Photovolt Res Appl 24:1284-1292

Wender BA, Foley RW, Prado-Lopez V, Ravikumar D, Eisenberg DA, Hottle TA, Sadowski J, Flanagan WP, Fisher A, Laurin L, Bates ME, Linkov I, Seager TP, Fraser MP, Guston DH (2014) Illustrating anticipatory life cycle assessment for emerging photovoltaic technologies. Environ Sci Technol 48:10531-10538. https://doi.org/10. 1021/es5016923

Wernet G, Bauer C, Steubing B, Reinhard J, Moreno-Ruiz E, Weidema B (2016) The ecoinvent database version 3 (part I): overview and methodology. Int J Life Cycle Assess 21:1218-1230

Woodhouse M, Goodrich A (2014) Manufacturing cost analysis relevant to single-and dual-junction photovoltaic cells fabricated with III-Vs and III-Vs grown on Czochralski silicon (presentation). National Renewable Energy lab.(NREL), Golden, CO (United States)

Yang F, Messing ME, Mergenthaler K, Ghasemi M, Johansson J, Wallenberg LR, Pistol ME, Deppert K, Samuelson L, Magnusson MH (2015) Zn-doping of GaAs nanowires grown by Aerotaxy. J Cryst Growth 414:181-186

Zhang J, Gao X, Deng Y, Li B, Yuan C (2015) Life cycle assessment of titania perovskite solar cell technology for sustainable design and manufacturing. ChemSusChem 8:3882-3891. https://doi.org/10. $1002 /$ cssc. 201500848

Publisher's note Springer Nature remains neutral with regard to jurisdictional claims in published maps and institutional affiliations. 